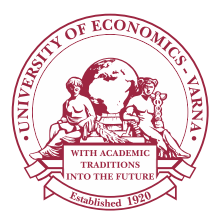

Izvestiya Journal of Varna University of Economics 2 (2021)

IZVEST I YA

Journal of Varna University of Economics

http://journal.ue-varna.bg

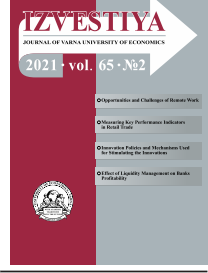

\title{
EFFECT OF PRODUCT ATTRIBUTE AND PRICING STRATEGY ON MULTINATIONAL FIRMS COMPETITIVENESS
}

\author{
Adeola E. ADETAYO ${ }^{1}$, Oludayo O. ARIYO ${ }^{2}$, Adebiyi J. ABOSEDE ${ }^{3}$
}

\footnotetext{
${ }^{1}$ Olabisi Onabanjo University, Ago-Iwoye, Ogun State, Nigeria,

E-mail: adeola.aina@oouagoiwoye.edu.ng

${ }^{2}$ Olabisi Onabanjo University, Ago-Iwoye, Ogun State, Nigeria,

E-mail: ariyo.oludayo@oouagoiwoye.edu.ng

${ }^{3}$ Olabisi Onabanjo University, Ago-Iwoye, Ogun State, Nigeria,

E-mail: adebiyi.abosede@oouagoiwoye.edu.ng
}

JEL: M30, M31, M37

Key words:

competitiveness;

marketing mix;

pricing strategy;

product attributes.

\begin{abstract}
In today's dynamic and turbulent environment, organizations are increasingly entering into the international market to sustain competitive advantage and explore special skills and knowledge and the need to improve their performance. This study examined how competitiveness could be achieved using product attributes and pricing strategy in Nigerian multinational firms. The survey research design was adopted. A structured questionnaire was employed in collecting data from 313 respondents in Nestle Nigeria Plc, Unilever Nigeria Plc, and P.Z. Cussons Nigeria Plc, which was obtained through Raosoft sample estimator at $95 \%$ confidence level and 5\% error margin using selected multinationals in fast-moving consumer goods. Categorical regression was used to determine the effect of product attribute and pricing strategy on multinational firms ' competitiveness in Nigeria. The study revealed that product attributes and pricing strategy have positive, significant, and joint effects on multinational firms ' competitiveness with coefficient and $p$-value of $\beta_{1}=0.288(p$-value $<0.000)$ and $\beta_{2}=0.289(p$-value $<0.000)$ at $\mathrm{F}$-stat $=67.795(0.000)$ and adj. $\mathrm{R}^{2}=0.381$. Therefore, it is concluded that competitiveness can be achieved using product attributes and pricing strategy. It is recommended that firms place greater emphasis on their products ${ }^{6}$ attributes and pricing to improve their competitiveness posture.

(C) 2021 University of Economics - Varna
\end{abstract}

Citation: ADETAYO, Adeola E., ARIYO, Oludayo O., ABOSEDE, Adebiyi J. Effect of Product Attribute and Pricing Strategy on Multinational Firms Competitiveness. Izvestiya Journal of Varna University of Economics, 65 (2), pp. 191-206.

DOI: 10.36997/IJUEV2021.65.2.191 


\section{Introduction}

The current dynamics in the business environment has caused multinational firms to transfer a certain part of their commercial practice to other countries while adapting their operations in such foreign countries because of less competition and lower intensity of rivalry in those countries. This action requires the firm to choose an operation area where its products and services could make a large impact. This is important to allow the interaction between the firm and society in markets where conditions and cultural forces might affect certain areas' products or services.

Globalization has made organizations increasingly face intense competition both in the domestic and the international arena. The level of competitiveness manifests the organization's ability to design, produce, and market products superior to those offered by competitors. Globalization will warrant entering the local and international markets, with improved marketing strategies to meet the consumers' needs and satisfaction (Doole and Lowe, 2008). Marketing practices are geared towards performance improvement and can be seen in the contexts of branding, pricing policy, applied marketing channels, and promotion activities (Kenesei, Gyulavari and Seer, 2013).

As pointed out by Kaleka and Morgan (2017); Karafyllia and Zucchella (2016); Dosi, Grazzi and Moschella (2015) marketing strategies showed how organizational competitiveness affects business performance (at both domestic and international level). Scholars such as Gbolagade, Adesola and Oyewale (2013); Mutambuki and Orwa (2014); Ebitu (2016) and Chukwuemeka (2016) observed that there is a causal relationship between marketing strategies and business performance in Nigeria. It could be seen, therefore, that competitiveness drives performance. It may be interesting then to see competitiveness from within and evaluate how internal marketing strategies can help to achieve it.

Various studies have examined how product attributes have influenced organizational performance, firm competitiveness, market share and price sensitivity (Mutambuki \& Orwa, 2014); Ebitu, 2016; Chukwuemeka, 2016 Lawal, 2012). However, to the best of the researchers ' knowledge, how product attributes drive pricing strategies among multinational firms is yet to be seen. The choice on the multinational firms is premised on Lawal's (2012) position who opines that multinational firms are drivers of developing economies prosperities. Therefore, this study seeks to evaluate internal strength (competitiveness) of multinational firms through product attributes and pricing strategy, which are presumed to be majorly controlled internally by the firms in Nigeria. 
Adeola E. Adetayo, Oludayo O. Ariyo, Adebiyi J. Abosede.

Effect of Product Attribute and Pricing Strategy on Multinational Firms Competitiveness

\section{Research Objectives}

i. to examine whether product attributes contribute positively to Nigerian multinational firms ${ }^{6}$ competitiveness among fast-moving consumer goods.

ii. to investigate the effect of pricing strategy on Nigerian multinational firms ${ }^{6}$ competitiveness among fast-moving consumer goods.

iii. to assess the combined effect of product attributes and pricing strategy on Nigerian multinational firms' competitiveness among fast-moving consumer goods.

The study was divided into five sections. Section one introduces the subject matter, section two presents a literature review, section three the research methodology employed for the study, section four the research findings and discussion of the findings and section five provides the conclusion and recommendations of the study.

\section{Review of Literature}

\section{The Concept of Marketing Mix Strategies}

Marketing mix strategies are determined by defining organizational goals and objectives. The Marketing strategy is the marketing logic by which the company hopes to create customer value and achieve profitable customer relationships. The marketing mix is a method used by the company trying to reach its targeted customers and outwit its competitor's. According to Aremu and Lawal (2012), the marketing mix strategy is defined as an analysis of the market and its environment, relating to customer buying behaviour and competitive activities. This marketing mix strategy is associated with the $4 \mathrm{P}^{\prime} \mathrm{s}$ of marketing i.e. product, pricing, place, and promotion, which defines the company's marketing objective and explains how it will be achieved in the future (Ibidunni, 2010); but these 4P's of the marketing mix have been further extended to $7 \mathrm{P}$ 's.

Marketing mix strategies are the methods adopted by the firm to outwit their competitors through product attributes and pricing strategies. The quality of the product is the key to ensuring customer satisfaction, and it is essential first to know the customer's needs. Their exact needs must be produced within a period to a minimum price set. The product can be determined in terms of packaging, labeling, size, design, texture and taste, timeliness in delivery, reliability, and potency. Product prices can also influence customers' buying behaviour.

\section{The Concept of Product Attributes Strategy}

The product attributes are the set of decisions made by the producers to meet the buyers" expectations regarding the question „What will the product offer by way of 
meeting the need gap and giving satisfaction?" The strategy focuses on how consumers" choices in terms of product design, packaging, brand positioning, and product guarantee are enhanced. Gilaninia, Taleghani, \& Azizi, (2013) defined a product as anything that intends to attract attention, acquisition, use, or consumption which can be marketed in order to meet the need or desire of the buyer. A product can be any physical object having a complex set of advantages with a good characteristic of quality, brand, design, durability, packaging, comfort, and style presented for sale, opined Indumathi and Dawood (2016); Oladele (2009). These attributes are expected to form the basis of attraction to the consumers and also stand the product out from substitutes. Therefore, it is imperative that organizations through their pre-production marketing would have identified the need gap and develop a product that will meet the need gap in a manner that attracts the attention of potential buyers.

\section{The Concept of Pricing Strategy}

Pricing can be a big challenge to an enterprise, especially where there are many substitutes, different cost elements, and the desire to make a profit. The primary reason for the employment of strategic tools is to create value for customers. According to Armstrong and Kotler (2013), companies need to make the right pricing decisions to develop a compelling marketing mix. Pricing is an element in the marketing mix and can be a vital and potent element in the international market. A product's price is the monetary exchange value for a given quantity and quality of goods or services or what to pay to use a product (Gilaninia, et al. 2013, Nwokoye, 2000). Underpricing or overpricing a product could have an adverse effect on sales (Waiswa, Nduhura, Mugerwa, Settumba, Wanume, \& Businge, 2016). Therefore, appropriate pricing is essential to drive the product purchase and set the table for competitiveness.

\section{Multinational Firm Competitiveness (M.F.C.)}

Market competition presupposes the existence of more than one organization in the market, requiring that each organization adopt an appropriate marketing strategy to remain afloat given the strengths and weaknesses of these firms. The style of promoting and enhancing competitiveness among organizations is partly determined by the current turbulent macro environment and the ability to control the microenvironment. Arguably, the strength within can determine, to a large extent, the level of competitiveness in the market. Competition is seen as a form of battle against other companies, focusing on strategies that are related to managing the dynamic environment, customer needs, and competitor's reaction in the market. Competitiveness has become more critical than ever for a business's survival and success in a dynamic environment. Barney (1991) views organization resources as key to promoting competitiveness in the market. The 
Adeola E. Adetayo, Oludayo O. Ariyo, Adebiyi J. Abosede.

Effect of Product Attribute and Pricing Strategy on Multinational Firms Competitiveness

idea is that once resources are unique and differentiated from those offered by other competitors; such an organization can sustain competitive advantages. Cost advantages allow the organization to set strategic price and dwell on product attributes by operating from internal strength.

\section{Theoretical Framework}

The study is anchored on the resource-based theory. Hamel and Prahalad popularized the resource-based theory in their book „Competition for the Future“ (1996), in which scholars viewed an organization as a set of resources that made their resources different from one another and allowed them to earn money in a competitive advantage over others. Barney (1991) argues that the competitive advantages of the organization are determined by valuable, scarce and non-substitutable resources and capabilities, and depend on the firms ${ }^{6}$ ability to make a unique and differentiated strategy. He believed that valuable elements, such as resources, should enable the organization to do things and behave in ways that increase sales or market share, reduce costs, increase margins or add financial value to businesses (Barney, 1986). He also pointed out that resources are useful when they enable an organization to design or implement strategies that improve its effectiveness and efficiency (Barney, 1991).

The resource-based theory (RBT) provides an important framework for explaining and predicting the foundations of a firm's competitive advantage and performance (Barney, Ketchen, \& Wright, 2011; Slotegraaf, Moorman, \& Inman, 2003; Vorhies \& Morgan, 2005), management researchers (Barney \& Hesterly, 2012)

This study rests on the resource-based theory since the intent is to see how internal strength can benefit organizations competing with one another in the same market place. The theory states that an organization's competitive advantages are determined by valuable, scarce, and non-substitutable resources and capabilities to push for unique and differentiated strategy. In this context, the study is exploring the possible effect of product attribute and pricing strategies to estimate the competitiveness of organizations in the international markets. It is believed that valuable elements, such as resources, should enable the organization to do things and behave in ways that increase sales or market share, reduce costs, increase margins, or add financial value to businesses.

\section{Product Attributes, Product strategy and Firm Competitiveness: The Nexus}

Ebitu, (2016) in his work marketing strategies and the performance of small and medium enterprises in Akwa Ibom State, Nigeria, used a survey design and a simple random sampling technique with a total sample size of 240 SMEs. Eighty small and medium-sized enterprises were selected in two local governments in each senate district. The statistical tool used for this study was PPMC analysis. The study found 
that the product quality and relationship marketing strategy significantly impacted the profitability and increased market share of S.M.E.s in Akwa Ibom State.

Chukwuemeka (2016) studies the influence of marketing strategies on I.C.F.s (indigenous construction firms) ' performance levels in south-south Nigeria. Targeted sampling was adopted for his study using primary questionnaire data with a sample of 87 C.E.O.s and CCI managers in the six states of Nigeria's south-south geopolitical zone. An ordinary regression analysis was used to achieve the study result, which revealed a significant difference in the frequency of use of marketing strategies by the best performing and [worst] performing I.C.F.s.

Ayedun, Oloyede, Oluwunmi and Oyedele, (2014) aim to examine the effect of the marketing strategies adopted by the wealth review and valuation firms operating in Kaduna metropolis and their impact on the performance of their enterprise, using primary and secondary data through questionnaires and self-structured journals, the directory of the Nigerian Institution of Inspectors and Estate Evaluators, among other sources, with a sample of 25 evaluation companies and estate appraisal in the metropolis of Kaduna. The result of the correlation revealed that the use of various marketing strategies had a positive impact on business performance. However, it was clear that the relationship between marketing strategies and business performance was positive. The study later suggested that more aggressive strategies were needed to improve their performance further.

Gbolagade, Adesola and Oyewale, (2013) study the impact of the marketing strategy on business performance, with particular reference to selected S.M.E.s in the Oluyole local government area in Ibadan, Nigeria. The survey design was used, which involves the use of a customized primary data questionnaire with a sample of 103 respondents. The instrument used is a closed questionnaire, and a correlation coefficient and multiple regression analysis were used to analyze the data using SPSS. The results show that marketing strategies (product, promotion, location, price, packaging, and after-sales service) were common predictors of corporate performance in terms of profitability, market share, return on investment, and expansion.

Felzensztein, Stringer, Benson-Rea and Freeman, (2014) study international marketing strategies in Clusters using primary data, with the help of a questionnaire in which a sample of 141 general managers or marketing managers was obtained. The data were analyzed using SPSS, and the results of the study make a significant contribution to the theory of agglomeration by confirming the importance of sharing marketing knowledge to create a sustainable competitive advantage in international markets. The study did not take into account agro-food industries such as manufacturing and other knowledge-intensive industries. The research did not compare clusters of agroenterprises and non-agro-industries in developed and emerging economies. It does not 
Adeola E. Adetayo, Oludayo O. Ariyo, Adebiyi J. Abosede.

Effect of Product Attribute and Pricing Strategy on Multinational Firms Competitiveness

examine the active marketing externalities and international competitiveness in the economies under consideration.

Masood, Saif, Sidra and Aamna, (2013) study the impact of the marketing strategy's creativity on organizational performance through the effectiveness of the implementation of the marketing strategy (empirical evidence of Pakistani organizations). Primary data were used from a survey questionnaire provided by key personnel of Pakistan's commercial service and manufacturing units. The regression analysis result showed that performance is optimized when an organization develops a creative strategy and achieves effective implementation. A practical data collection technique has been used for the study. Still, it is possible to study the possibility of using a cross-sectional research design that will increase the generalization. Besides, only one respondent from each organization was also used, while multiple respondents were not captured and that may increase the reliability of the results.

Oke, (2013) examined the effect of marketing strategies and bank performance in Nigeria using primary and secondary data in the form of questionnaires, CBN publications, and the Nigerian Stock Exchange database. Standard Least Squares and multiple regression techniques show that marketing has become a significant function of the banking sector because of the increased competition brought about by consolidation and banking reforms. The study also shows the overall importance of the marketing variables retained, although the effect is noticeable when it comes to marketing isolated from other variables. This helps to conclude that marketing strategy techniques need to be combined appropriately to improve performance.

Griffith (2010) examined the understanding of the effects of multi-level institutional convergence on international market segments and the global marketing strategy. The study was conducted in the United States using primary data by research. The results are significant because of their theoretical and managerial contributions to understanding the change of the marketing segment and their implication for the global marketing strategy. This study is limited by its focus on institutional effects at the macro level that can be decomposed. The research focuses on one element of the overall marketing strategy, that is, marketing mix elements and not on broader marketing strategy issues. 


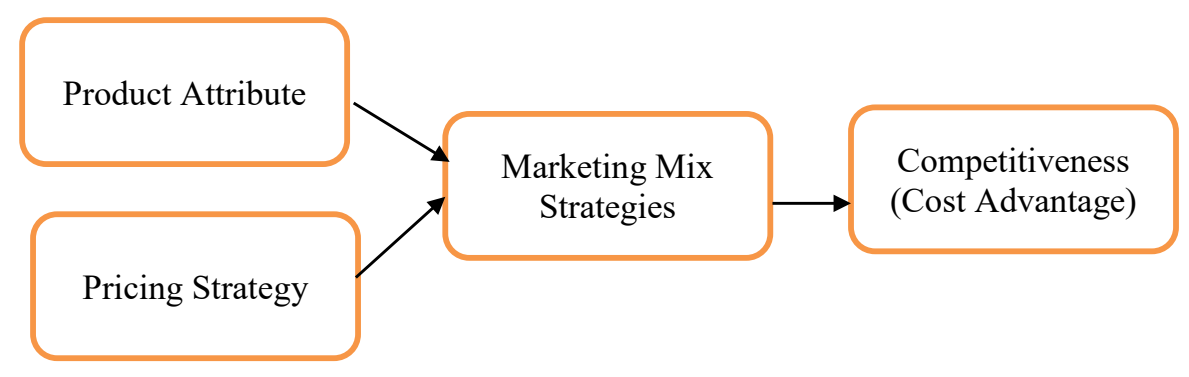

Figure 1: Marketing Mix Strategies and Competitiveness

\section{Methodology}

The survey research design was used to capture variables relevant to the study. The population of the management staff in marketing, finance and strategy departments of Nestle Nigeria Plc., Unilever Nigeria Plc. and P.Z. Nigeria Plc. of Fast Moving Consumer Goods chosen for this study were 1680 (Annual financial statements for the year 2016). Stratified sampling techniques were used to select management staff in each company as respondents based on their size because they are heterogeneous in nature. Raosoft sample estimator software was used to determine the aggregate sample size of 313 management staff at 95\% confidence level and 5\% margin for the study. However, from the 313 questionnaires distributed, only 218 were filled and returned appropriately. The questionnaire adopted a five-point Likert scale ranging from 1 (least agreed) to 5 (most agreed). The questionnaires were personally administered with the aid of 3 research personnel in December, 2018 and fully retrieved, April, 2019.

In determining the validity of the research instruments employed for this study, the content, construct, and expert validity was used. In achieving expert validity, the tool (questionnaire) was reviewed by the expert in academia, and the correction was made accordingly, to validate the content. The content validity was achieved through a pilot study where a test-retest method was employed. The test-retest method was used to test for the consistencies of the instruments. Questionnaires were administered twice to a group of 20 respondents who are not part of the sample size within a two week interval. The result from the first and second tests were correlated. The Cronbach alpha was adopted to fulfill the reliability test further. The Cronbach alpha coefficient reveals $\alpha=0.76,0.83$ and 0.81 respectively for the product attributes, pricing strategy and competitiveness respectively. The construct validity was achieved by the researchers through carefully adapting the measures from studies that have employed such variables and are similar in objectives (Oke, 2013; Aremu \& Lawal, 2012). Only specific questions that assess known measures of depression must be included in the 
Adeola E. Adetayo, Oludayo O. Ariyo, Adebiyi J. Abosede.

Effect of Product Attribute and Pricing Strategy on Multinational Firms Competitiveness

questionnaire. The categorical regression was utilized in the analysis of data with the aid of the Statistical Package for the Social Sciences (SPSS) version 23.

\section{Model specification}

The model aggregates the effect of product attribute and pricing strategy; it is estimated to examine how these elements individually or jointly affect the competitiveness of multinational firms in Nigeria. The model addresses the study's main objective, which is to investigate the effect of Product Attributes and Pricing strategy on multinational firms' competitiveness in Nigeria. The model is thus mathematically expressed;

$$
\begin{aligned}
& M F C=f(P S) \\
& M F C=B_{0}+B_{1} P S+\mu \\
& M F C=f(P A) \\
& M F C=B_{0}+B_{1} P A+\mu \\
& M F C=f(P S, P A) \\
& M F C=B_{0}+B_{1} P S+B_{2} P A+\mu
\end{aligned}
$$

Where:

MFC represents Multinational Firm Competitiveness;

$\beta_{0}$ is the constant term;

$\beta_{1}, \beta_{2}$ are the coefficient of the estimator;

$\beta_{1}, \beta_{2}>0$;

$\mathrm{PA}=$ product attribute;

$\mathrm{PS}=$ pricing strategy;

$\mu$ are the error term.

For the apriori expectation, it is expected that product attributes and pricing strategy have a positive effect on multinational firm competitiveness in Nigeria; hence the parameters of a pricing strategy should have a positive sign.

\section{Research Hypotheses}

$\mathbf{H}_{01}$ : Product attributes do not contribute significantly to Nigerian multinational firms' competitiveness among the fast-moving consumer goods.

$\mathbf{H}_{\mathbf{0}}$ : There is no significant positive effect of pricing strategy on Nigerian multinational firms" competitiveness among the fast-moving consumer goods.

$\mathbf{H}_{03}$ : Product attributes and pricing strategy do not significantly affect Nigerian multinational firms" competitiveness among the fast-moving consumer goods. 


\section{Results and Discussion of Findings}

\section{Descriptive Statistics}

Fig. no. 1 shows the degree of agreement of respondents to how product attributes affects firm competitiveness. The graph shows that most of the respondents are of the opinion that product attributes are pivotal to competitiveness.

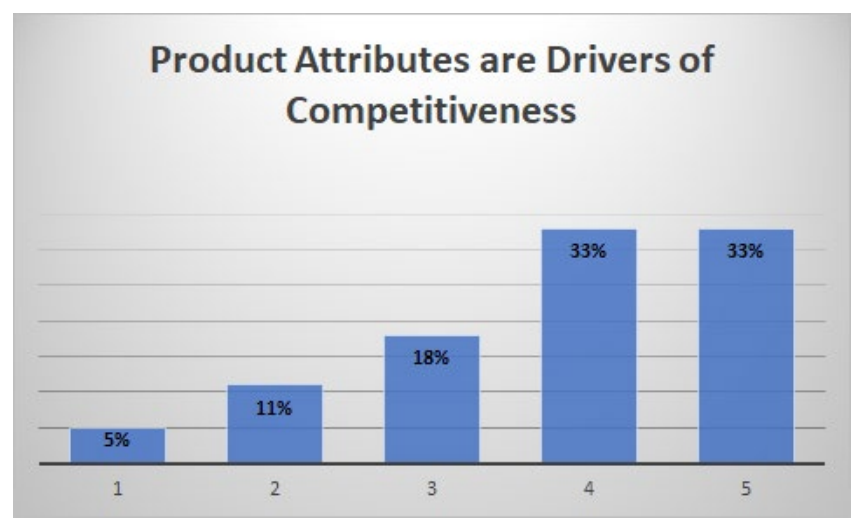

Fig. no. 1. Product attributes strategies influence firm competitiveness

Source: authors 'own projection

Fig. no. 2 shows the degree of agreement of respondents to how pricing decisions influence firm competitiveness. The analysis reveals that most of the respondents are of the opinion that pricing strategy is important to firms achieving competitiveness.

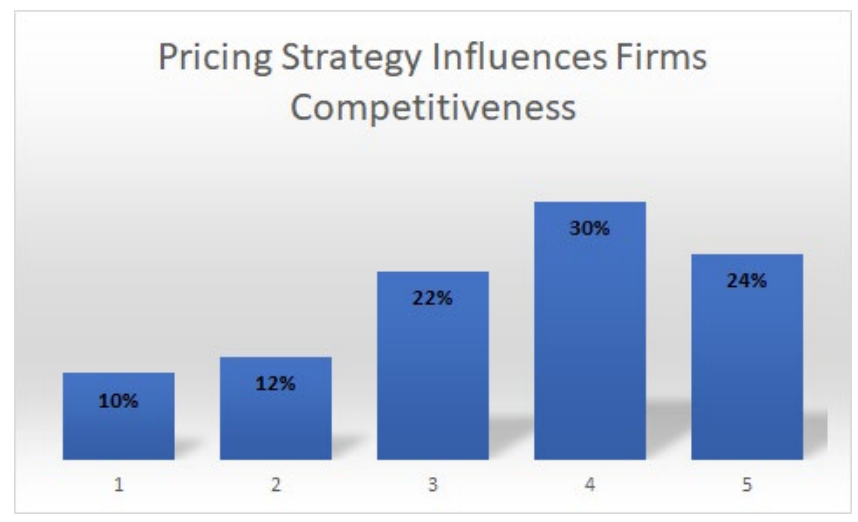

Fig. no. 2. Pricing strategy influences firm competitiveness Source: authors ' own projection 
Adeola E. Adetayo, Oludayo O. Ariyo, Adebiyi J. Abosede.

Effect of Product Attribute and Pricing Strategy on Multinational Firms Competitiveness

\section{Hypotheses testing}

We expect that product attributes do not contribute significantly to Nigerian multinational firms' competitiveness among fast-moving consumer goods.

Table no. 1

\section{Regression Result for Hypothesis 1}

\begin{tabular}{cccccc}
\hline \multicolumn{5}{c}{ Competitiveness } \\
\hline Variable & $\mathrm{B}$ & $\mathrm{SE}$ & $\beta$ & $\mathrm{tc}=$ & $\mathrm{P}$ \\
\hline Product Attributes & 0.511 & 0.06 & 0.516 & 8.680 & 0.000 \\
$\mathrm{R}^{2}$ & & 0.268 & & & \\
$\mathrm{~F}$ & & 87.626 & & & \\
& & $\mathrm{p}=0.000$ & & & \\
\hline
\end{tabular}

Source: Researcher's fieldwork (2018)

Table no. 1 reveals the significance of relationship and effect $(\beta=0.516)$ of product attributes on competitiveness. The coefficient of determination $\left(\mathrm{R}^{2}=0.268\right)$ reveals that product attributes ${ }^{6} 26.8 \%$ variation in competitiveness is explained. The standard error ( $\mathrm{SE}=0.06$ ) establishes that the model is a good fit by revealing how product attributes predict competitiveness since the value falls between the accepted estimates. This also indicates that product attribute is a significant driver of firm's competitiveness. The unstandardized coefficient $(\mathrm{B}=0.511)$ shows that for every unit increase in product attributes, competitiveness increases by 0.511 units. The t-value ( $t$-value $=8.680$, $\mathrm{p}=0.000$ ) establishes that product attributes significantly affect competitiveness. The result establishes that product attributes significantly affect firm's competitiveness in multinational companies.

Table no. 2

\section{Regression Result for Hypothesis 2}

\begin{tabular}{cccccc}
\hline \multicolumn{5}{c}{ Competitiveness } \\
\hline Variable & $\mathrm{B}$ & $\mathrm{SE}$ & $\mathrm{B}$ & $\mathrm{tc}=$ & $\mathrm{P}$ \\
\hline Price Strategy & 0.418 & 0.06 & 0.422 & 14.293 & 0.000 \\
$\mathrm{R}^{2}$ & & 0.268 & & & \\
$\mathrm{~F}$ & & 106.175 & & \\
& & $\mathrm{p}=0.000$ & & \\
\hline
\end{tabular}

Source: Researcher's fieldwork (2018) 
Table no. 2 reveals the significance of relationship and effect $(\beta=0.422)$ of price strategy on the competitiveness of multinational firms. The coefficient of determination $\left(\mathrm{R}^{2}=0.268\right)$ reveals that $26.8 \%$ variation in competitiveness is explained by price strategy. The standard error ( $\mathrm{SE}=0.06$ ) establishes that the model is a good fit by revealing how price strategy predicts competitiveness since the value falls between the accepted estimates. This also indicates that price strategy is a significant driver of firm's competitiveness. The unstandardized coefficient $(B=0.418)$ shows that for every unity increase price strategy, competitiveness increases by 0.418 units. The $\mathrm{t}$-value (t-value $=14.293, \mathrm{p}=0.000$ ) establishes that price strategy significantly affects competitiveness. The result establishes that price strategy significantly affects the firm's competitiveness in multinational companies.

Table no. 3

\section{Regression Result}

\begin{tabular}{cccc}
\hline Variable & Coefficient & T & Sig \\
\hline Constant & 13.344 & 8.087 & 0.000 \\
PA (2) & 0.288 & 4.478 & 0.000 \\
PS (1) & 0.289 & 5.866 & 0.000 \\
Adj. $\mathrm{R}^{2}=0.381$ & & & F-stat $=67.795$ \\
& & & $(0.000)$ \\
\hline
\end{tabular}

Source: Researcher's fieldwork (2018)

Table no. 3 indicates that product attributes and pricing strategy have a significant combined effect on Nigerian multinational firm competitiveness, with F stat of 67.795 and probability value of 0.000 , which reveals that product attribute and pricing strategy have a positive and significant combined effect on Nigeria Multinational Firm Competitiveness at $5 \%$ level of significance. The adjusted coefficient of determination $\left(\right.$ Adj. $\mathrm{R}^{2}$ ) indicates that product attributes and pricing strategy account for $38.1 \%$ variation in Nigeria's multinational firm competitiveness.

\section{Discussion of findings}

Findings revealed and indicated that product attributes significantly affect Nigeria's multinational firm competitiveness. Hence, product attributes are the set of decisions that a marketer takes regarding the question ,what to produce and sell?" and the strategy involves the choices made on product design, the design of the elements of the product mix, packaging, branding, product positioning, product warranty, etc. Gilaninia, et. al. (2013) said a product is anything for attention, acquisition, use, or 
Adeola E. Adetayo, Oludayo O. Ariyo, Adebiyi J. Abosede.

Effect of Product Attribute and Pricing Strategy on Multinational Firms Competitiveness

consumption that can be marketed and can satisfy a need or want. Thus, Nigeria multinational firm competitiveness in the global market increases because product attributes contribute effectively to the ability of an organization to improve the quality of their product in terms of branding, packaging, etc. by gaining the interest of their customers to buy more of their product rather than the competitors own. This study is consistent with the study by Ebitu, (2016); Ayedun, et. al. (2014); Gbolagade, et. al. (2013); Owomoyela, et. al. (2013); Kazem and Heijden (2006); Ogunmokun and Esther (2004). Findings also showed that pricing strategy significantly affects Nigeria's multinational firm competitiveness in the international market. Hence, pricing strategy is one of the main problems that marketing managers face in the market and also serves as the critical strategic tool used to create value for customers. This study is consistent and supported by the survey by Ayedun, Oloyede, Oluwunmi and Oyedele (2014); Gbolagade, Adesola and Oyewale (2013); Griffith (2010). Findings revealed that product attributes and pricing strategy individually have a positive and significant effect on Nigeria's multinational firm competitiveness. The combined impact equally showed a positive and significant impact on Nigeria's multinational firm competitiveness. This is consistent with the study by Ebitu (2016); Ayedun, Oloyede, Oluwunmi and Oyedele (2014); Gbolagade, Adesola, and Oyewale (2013); Griffith (2010) as explained. Consequently, the study further revealed that product attributes and pricing strategy serve as the engine that drives their firm to compete with others to expand their market share and add more profit to their sales. Resource-based view theory was adopted in line with the study, especially in Nestle Nigeria Plc., Unilever Nigeria Plc. and P.Z. Cussons Nigeria Plc.

\section{Conclusion and Recommendation}

The study examined the effect of product attributes and pricing strategy on firm competitiveness. The study established that the two dimensions of marketing mix strategies measured in product attributes and pricing strategies are significant drivers of competitiveness in multinational firms. The analysis establishes that the strategies significantly affect multinational firm competitiveness. The individual dimension asserts that product attributes are the most significant measures of marketing mix strategies driving multinational firm's competitiveness in the international market. Based on the findings, the study suggests that multinational companies should pay more attention to product features which will be acceptable in the countries where their firms operate.

The findings also establish that multinational firms should offer competitive prices in order to create, maintain and sustain competitiveness. This is based on the findings of the study which reveal that pricing strategy enhance and influence competitiveness. 
The empirical findings of this study provide evidence that product attributes and pricing strategy plays an essential role in Nigeria's multinational firm competitiveness in the international markets. The two elements: product attributes and pricing strategy have individual positive and significant effect. It is also worthy to note that in the joint analysis of the dimensions of strategies, the product attributes are the most significant construct. The study recommends that multinational firms should concentrate more and make use of the best strategies (product attribute) in order to attain and sustain competitiveness.

\section{Research limitations and future works}

Further studies are required to develop new hypotheses, by considering other elements of marketing mix strategies; this is because the two aspects of marketing mix strategies (product attribute and pricing strategies) employed in this study only account for $38 \%$ variation in marketing mix strategies. Therefore $62 \%$ variation in marketing mix strategies is accounted for by other factors not captured by this study. Furthermore, other multinational firms in other sectors can be considered.

\section{References}

1. Aremu, M. \& Lawal, A. (2012). Exploring marketing strategy as a catalyst for performance in the Nigerian telecommunication industry. International Journal of Marketing and Business Studies, 2(4), pp. 65-71.

2. Armstrong, G. \& Kotler, F. (2013). Vavedeniev marketinga. Sofia: Parvoizdanie, Klasika

3. Ayedun, C. A., Oloyede, S. A., Oluwunmi, A. O. \& Oyedele, M. (2014). The effect of marketing strategies on corporate performance of estate surveying and valuation firms in Kaduna metropolis of Nigeria. American International Journal of Social Sciences, 3(4), pp. 202-209.

4. Barney, J. (1991). Firm resources and sustained competitive advantage. Journal of Management, 17(1), pp. 99-121.

5. Barney, J. B. (1986). Strategic factor markets: Expectations, luck, and business strategy, Management Science, 32(10), pp. 1231-1242.

6. Barney, J., Ketchen, D. \& Wright, M. (2011). The future of resource- based theory: Revitalisation or decline? Journal of Management, 37(5), pp.1299-1315.

7. Barney, J. \& Hesterly, W. (2012). Strategic management and competitive advantage: Concepts and cases $\left(4^{\text {th }}\right.$ ed.). New Jersey: Pearson

8. Chukwuemeka, P. O. (2016). Marketing strategies and performance of 
Adeola E. Adetayo, Oludayo O. Ariyo, Adebiyi J. Abosede.

Effect of Product Attribute and Pricing Strategy on Multinational Firms Competitiveness

indigenous construction firms in Nigeria. Journal of Construction in Developing Countries, 22(1), pp. 1-19.

9. Doole, I. \& Lowe, R. (2008). International marketing strategy analysis, development and implementation, $5^{\text {th }}$ Edition, British Library Cataloging

10. Dosi, G., Grazzi, M. \& Moschella, D. (2015). The determinants of international competitiveness: a firm-level perspective. Research Policy, 44(10), pp. 1796-1814.

11. Ebitu, E. T. (2016). Marketing strategies and the performance of small and medium enterprises. British Journal of Marketing Studies, 4(5), pp. 51-62.

12. Felzensztein, C., Stringer, C., Benson-Rea, M. \& Freeman, S. (2014). International marketing strategies in industrial clusters: Insights from the Southern Hemisphere. Journal of Business Research, 67(5), pp. 837-846.

13. Gbolagade, A., Adesola, M. A., \& Oyewale, I. O. (2013). Impact of marketing strategy on business performance. Journal of Business and Management, 11(4), pp. 59-66.

14. Gilaninia, S., Taleghani, M., \& Azizi, N. (2013). Marketing Mix and Consumer Behavior. Kuwait Chapter of the Arabian Journal of Business and Management Review, 2(12), pp. 53-58.

15. Griffith, D. A. (2010). Understanding multi-level institutional convergence effects on international market segments and global marketing strategy. Journal of World Business, 45(1), pp. 59-67.

16. Ibidunni, S. O. (2010). Marketing research for excellence. Concept publications Lagos, Nigeria.

17. Indumathi, N, \& Dawood, A. K. (2016)). Impact of marketing mix on consumer buying behavior in organic. International Journal of Research in Finance and Marketing, 6(10), pp. 43-54.

18. Karafyllia, M. \& Zucchella, A. (2016). Synergies and tensions between and within domestic and international market activities of firms. Strategic Management Journal, 38(6), pp. 1356-1370.

19. Kazem, A., Heijden, B. V. D. (2018). Exporting firms' strategic choices: the case of Egyptian S.E.M.s in the food industry (S.A.M.).Advanced Management Journal, 7(3), pp. 21-33.

20. Kaleka, A. \& Morgan, N. A. (2017). How marketing capabilities and current performance drive strategic intentions in international markets. Industrial Marketing Management, 78, 108- 121.

21. Kenesei, Z. S., Gyulavari, T. \& Seer, L. (2013). The role of marketing incorporates competition: marketing practice analysis of Hungarian companies. Management and Marketing Journal, University of Craiova, Faculty of Economics and Business Administration, 0(1), pp. 7-28. 
22. Masood, U. H., Saif, U. Q., Sidra, S. \& Aamna, M. (2013). Impact of marketing strategy creativity on organisational performance via marketing strategy implementation effectiveness: Empirical evidence from Pakistani Organisations. Journal of Scientific Research, 16(2), pp. 264-273.

23. Mutambuki, M. K. \& Orwa, B. H. (2014). Marketing strategies of commercial fish farming under the economic stimulus program (E.S.P.) in Kenya: An empirical study of Kitui County. International Journal of Humanities and Social Science, 4(1), pp. 1-8.

24. Nwokoye, N. G. (2000). Modern Marketing for Nigeria. Onitsha: African Publishers.

25. Ogunmokun, G. O. \& Esther, L. L. (2004). Product development process and performance of export ventures: a study of exporting companies in the People's Republic of China. Journal of Asia Pacific Marketing, 3(2), pp. 84-98.

26. Oke, M. O. (2013). Marketing strategies and bank performance in Nigeria: A Post- Consolidation Analysis. Global Journal of Management and Business Research, 12(12), pp. 2249-4588.

27. Oladele, O. (2009). Essentials of Marketing Management. Lagos Niyak Print and Publications.

28. Owomoyela, S. K., Oyeniyi, K. O. \& Ola, O. S. (2013). Investigating the impact of marketing mix elements on customer loyalty: An empirical study on Nigeria Breweries Plc. Interdisciplinary Journal of Contemporary Research in Business, 4(11), pp. 485-496.

29. Slotegraaf, R., Moorman, C. \& Inman, J. (2003). The role of firm resources in returns to market deployment. Journal of Marketing Science, 40(3), pp. 295-309.

30. Vorhies, D. \& Morgan, N. (2005). Benchmarking marketing capabilities for sustainable competitive advantage. Journal of Marketing, 69(1), pp. 80-94.

31. Waiswa, B. E., Nduhura, A., Mugerwa, B., Settumba, J. P., Wanume, P. \& Businge, H. (2016). Marketing strategies and market performance on M-Sente, a mobile money product of Uganda Telecom Ltd. Universal Journal of Management, 4(10), pp. 5 of 59-564. 